\title{
Fiat Auto: Industrial Relations Lost in Globalization
}

\author{
Paolo Caputo*, Antonino Campenni**, and Elisabetta Della Corte ${ }^{* * *}$
}

\author{
Dipartimento di Sociologia e di Scienza Politica, Università della Calabria, Rende, Italy, \\ *caputo@unical.it, ${ }^{* *}$ a.campenni@unical.it, *** dcorte@unical.it
}

\begin{abstract}
In the actual context of globalization, carmakers face a highly competitive market. The pace of technological innovation, the increase in international competition, the saturation of markets and the shortening of product lifespan are but some of the factors requiring a new organization of production. In order to face these radical changes, carmakers are implementing new strategies, not only by embracing the concept of globalization, but also by promoting changes in labour management practices, work organization and industrial relations. The aim of this paper is to analyse the impact of Fiat's new managerial strategies in response to increased global competition on the situation of the industrial relations, on the role of the Un-ions and on the condition of workers. These strategies include an intensification of work, shift and wage flexibility, plus a severe limitation of workers' rights (including the right to strike). On the one hand, such a strategy was presented and justified to the workers and the public as an objective necessity of global economy, and was even submitted to a referendum; on the other, the process was conducted unilaterally, under the recurring threat of transferring production abroad if the workers and their Unions refused to accept the new method. This brought to a split of the Unions and dialogue was maintained only with collaborative organisations, causing the discrimination of the other Unions and a situation of great dissatisfaction amongst all the workers. Through the words of workers and Union activists, the research showed evidence of the failure of claims that new management strategy can ensure both productivity and a new form of workplace democracy in the post-fordist factory. Despite new labour-saving technologies, lean production organisation and the adoption of new metric systems (such as Ergo-UAS); car industry would need, more than in the past, the involvement and active participation of Unions and workers. On the contrary, the paper points out how Fiat's actual form of production organization generates new tensions and increases employee's discontent, likely to ignite industrial conflict.
\end{abstract}

Keywords: Industrial Relations, Globalization, Conflict, Car Industry, Work Organization

\section{Introduction}

In the last two decades the car industry has gone through a radical transformation in response to three major constraints, intertwined with each other: the progressive saturation of car markets in old industrial countries; the consequent intensification of competition on a global scale; the longdrawn-out crisis of classic Fordist-Taylorist model of work organisation, accelerated by the Japanese competition experimenting new organisation models since the 1970s. We can single out three basic structural changes in response to such constraints. The first is related to the fact that car companies shifted their focus from national to global markets. This means changes in market scope, new regimes of competition and also new forms of organization of production on a global level. Secondly, most of the Original Equipment Manufacturers (OEM) experienced different productive organization models, trying to move from the traditional Fordist scheme to new work organization models (such as Just-In-Time, Lean Production, World Class Manufacturing and so on). Finally, we can observe a new organization of the inter-company relationships based on modularization, outsourcing and the creation of global production networks, all aimed at reducing vertical integration and increasing operational flexibility (spatial-geographic) of corporations.

In these years Fiat, under the leadership of manager Sergio Marchionne, was one of the chief protagonists of such big changes on a global scale. This paper will be mainly focussed on industrial relations and work conditions, but Marchionne's strategy reached far beyond that. Among other things that cannot be taken into account here, at least the operation of acquisition of a big American brand, such as Chrysler, must be mentioned. This is a striking example of Fiat strategy in substituting old national markets with new, more promising ones. At the time we are writing, Chrysler sales have risen by $40 \%$ in the United States, whilst Fiat accepted to lose $26.5 \%$ in Italy, where a historic plant - that of Termini Imerese in Sicily - was shut down at the end of 2011. There is now great concern among the workers of all the other productive sites in Italy.

Fiat is therefore now operating as a full global actor, morally free from any 'national' obligation ${ }^{1}$, directing investments where they promise to be more fruitful, in the perspective of creating a new automotive global group, Fiat-Chrysler (Berta 2011). This process is, however, conditioned by the

\footnotetext{
${ }^{1}$ As stated by Marchionne himself: "Whoever runs Fiat has the right and the duty to choose for his investments the most convenient localisation" ("II Sole - 24 Ore” April 5, 2012).
} 
structural characteristics of the automotive industry, which, unlike other industries such as Information Technology, links them much more closely to the countries of origin, as we argue in the next paragraph. This is why the institutional context and the situation of industrial relations are at the centre of Marchionne's strategy.

This paper is an attempt at showing the impact of Fiat's strategy on the very ground of industrial relations, on the role of the Unions and on the condition of workers in two countries, Italy and the Argentine. It is based on an on-going research focussed on the Fiat plant in Melfi, in Southern Italy - started back in the 1990s - plus recent fieldwork in Cordoba, Argentine ${ }^{2}$. After a short analysis of the main characters of the globalisation paths followed by big automotive corporations, the paper concentrates on some major issues concerning the Fiat case. Paragraph 3 locates the facts of today in the long history of work organisation changes at Fiat, where a constant element was a typical authoritarian 'style' in industrial relations. Paragraph 4 shows the kind of impact on the situation of workers of the intensification of work and of flexibility in shifts, combined with a stricter discipline. Paragraphs 5 and 6 illustrate the tactics followed both in Italy and Argentine to weaken the resistance of the Unions. By the creation of new companies, where new agreements would be applied (amended of all historical concessions), Fiat is now free from the application of national collective agreements, trying at the same time to get round national labour laws. Finally, Paragraph 7 deals with a specific aspect of work organisation, the introduction of the Ergo-UAS dispositive, with all its contradictions.

\section{The Globalisation of the Automotive Industry and its Impact on Industrial Relations}

The combination of neoliberal globalisation (Harvey 2010), internal reorganization and restructuring of the value chain is a common trend for national motor industries, showing a high homogeneity over the last ten years. The homogeneity of the development is supported by the fact that the final production of automobiles is, basically, concentrated in less than a dozen of more or less globally operating companies. The ever-increasing concentration of final producers guarantees a high convergence of development. Differences, of course, do exist because of the different production systems developed over time by the companies (Bélis-Bergouignan et al. 2000; Boyer and Freyssenet 2003), but they seem to be more in intensity than in substance. Based on variably developed systems of benchmarking, the big OEMs are increasingly trying to learn from each other in a context of growing competition. Concepts like 'outsourcing' or 'module strategies' are regarded as best practice and lead to a kind of organizational mimesis, at least to a certain degree.

The important role of the OEMs in the sector depends largely on the fact that they are still the protagonists in developing products and defining standards dominating the car industry. At the same time, supplier relationships have crucially changed due to trends like the reduction of vertical integration, the adoption of Just-In-Time solutions, global sourcing, simultaneous engineering and so on. Suppliers have become much more important for both the production and the development of more complex car components such as modules or systems. Nevertheless, what has not changed yet - and will not do so in the near future - is the role of OEMs in defining products and standards. Therefore, OEMs are still the protagonists along the value chain, although their contribution to the production of value is steadily decreasing. This is an important point for understanding both the homogeneity of organizational development within the sector and the specificity of the globalization path related to other sectors. The dominant reorganization model in the automotive industry is completely different from that dominating other globalised industries as, for instance, the production of hardware in the Information Technology industry, characterized by the fact that global operating suppliers play a central role in defining product standards and that production and development are decoupled to a large extent.

\footnotetext{
2 The empirical evidence for this paper is based on a cross-national comparison of the European automotive industry (Dynamo research project no. CIT2-CT-2004-508521), followed by qualitative research on the Fiat Auto case in Italy and Argentina. Semi-structured interviews were conducted at different times between 2000 and 2011 at the plants of Melfi, in Sothern Italy, and that of Cordoba, Argentine, for a total of 82 interviews. The aim of the fieldwork was to learn about workers' conditions and quality of life. In particular, we wanted to assess the impact of the new organisation of work and related control devices on workers and their individual and collective response. The interview guide was inspired by that used by the research group of Quaderni Rossi on Fiat in the 1970s (Lanzardo 1965), adjusted on the basis of changes inside and outside the factory. The interviewees were mostly active Fiat workers, sampled through snowballing techniques, plus a smaller number of union representatives, managers and other testimonials.
} 
This pathway of globalization is called 'Wintelism' in literature (Borrus and Zysman 1997). The potential implications for industrial relations are highly different. Whilst in Wintelism production is mainly transferred to low cost areas, with only the development, construction and marketing functions remaining in the developed capitalistic economies, in the automotive industry development and production remain much more closely linked. Globalization pressure in the automotive industry will therefore be dealt with to a much larger extent within the industrial relations systems of the developed countries (Jürgens et al. 2003), whereas in the IT-industry at least the relocation of production can hardly be avoided and globalization pressure within the developed economies is concentrated on the development functions.

The consequences of international integration and reorganization of the value chain are affecting all the companies in a similar way. Outsourcing by the OEMs, price pressure on suppliers, regime competition and forced comparisons between locations are exerting new pressures on industrial relations systems and labour standards in all countries. The industrial relations systems analysed in our study are facing common organizational and structural changes because of the decisive role of OEMs in the car industry. Countries, regions and territories, together with labour standards and institutional frameworks, are the playground on which the process of global reorganization of the value chain is taking place. Therefore, in the car industry globalization is more than a catchword. One of the characteristics of globalization in the car industry is the fact that productive locations are tightly integrated into systems of parallel production and therefore, to a certain degree, exchangeable.

Just to give an example of the impact of interrelated production on the workforce performance, we can quote a Fiat-Cordoba employee: "When Brazil asks for more cars, we have to make them. Last year [...] we had to make 150 Palios more a day to send to Venezuela, and we gave up our vacations to complete those Palios. We had to send those Palios to Venezuela [...] this production counts as extra hours. We are overcharged with hours. For the very reason that we don't have the other work shift, they overcharge, to have production done. [...] When there is more production they become crazy because they ask us, for example, "this month you have to make 10,000 cars"! And you have to make them, you have to make 10,000 cars. They make you do many more extra hours, make you come on Saturdays, on Sundays." ${ }^{3}$.

These situations have been common in the last few years, and this is what is making employment insecure and labour representatives vulnerable to concession demands by the management. However, it has to be borne in mind that labour is on the defensive and this is mainly a result of the globalization process (Gallino 2000 and 2007).

\section{Work Organization and Industrial Relations at Fiat}

Work organization and industrial relations at Fiat have changed greatly during the past fifty years, with an intensification over the last twenty (Motta and Barbero 2007). Before looking at the current stage, we wish briefly to review the changes in industrial relations and in the organization model since the Second Post-war era. Fiat has never really managed to build a consistent relationship between the adopted organization model and the relative industrial relations system, with a negative feedback on the efficiency of the former (Rieser 2011). Rieser claims that this is due to a persistent inability for Fiat to accept a model of industrial relations based on the acceptance of conflict as a physiological part of the business. This contradiction between the organization model and industrial relations is not an episodic event. In this time span, the Fiat model of industrial relations has generally been authoritarian, with the marginalisation of noncollaborative employees or Unions excluded. This was the case with Cgil ${ }^{4}$ between 1954 and 1958 , neutralized by manager Vittorio Valletta through selective dismissal of Union activists and workers who were members of the Communist or the Socialist Parties (Fiat used to keep special 'political' files on their employees, helped in this by the Police authorities), a strategy of separate agreements with $\mathrm{Cisl}^{5}$ (Accornero, Pizzorno et al. 1977, 30-31). Those were the days of the Taylorist model of production that equalled consistently Valletta's authoritarian style in work relations. The persistence of that model, based on Taylorism and on the role of 'collaborative' unions, was aided by the favourable economic conjuncture, the industrial boom. In this favourable

\footnotetext{
${ }^{3}$ Interview with a Fiat worker by Lorena Capogrossi and Elisabetta Della Corte. Cordoba, 29 November 2010

${ }^{4}$ The Confederazione Generale Italiana dei Lavoratori, CGIL, with this name since 1945 (it was founded in 1908 as the first Italian general workers' Union), has always been the most representative Union in Italy; traditionally of communistsocialist orientation.

${ }^{5}$ The Confederazione Italiana Sindacati Lavoratori, CISL, was born in 1950 as a consequence of a split from Cgil in the context of harsh political confrontation of the cold war. Of catholic orientation, it is the second largest Italian union.
} 
scenario, Fiat managed to guarantee both employment and wage levels in order to improve worker's acquiescence for most of the 1950s.

Internal contradictions within the factory system exploded in the 1960s, first for the signature of a separate agreement in 1962 (this time with $\mathrm{Uil}^{6}$. The episode caused a three-day riot in Turin) and later in 1968-69. These events showed a relevant change in the balance of power in favour of the workers, inside and outside the factory, supported by the revitalizing participation of other young workers and the student movement. If the 1950s are remembered as a time of acquiescence, the 1960s are the years of unpredictable resistance and struggles.

The balance of power in favour of the workers went on throughout the 1970s, until the harsh defeat in autumn 1980. At that time Fiat managed to dismiss 24,000 workers (amongst whom were many shop-stewards and the bulk of unionized workers). Only a small portion of them was permitted to come back to work in the following years. Workers' resistance took the shape of a 35day-long occupation of the large Mirafiori plant in Turin. In order to defeat it, Fiat (whose general administrator at that time was Cesare Romiti) secretly organized a protest of the employees that were closer to the management. A 40,000-strong demonstration of Fiat cadres, white-collar workers and even guardians marched through Turin under the 'we claim our right to work' slogan. The demonstration had a huge symbolic impact, granting Fiat's victory over the workers movement (Giachetti and Scavino 2005).

The Fiat model of industrial relations has always been authoritarian in Argentina, too. A further change in labour relations has been taking place since the 1990s, when Fiat decided to return to produce directly in the South American country. In 1995, the Italian corporation created the Fiat Auto Argentina Company and started the construction of a new plant in Cordoba (incorporating the old Cormec engine plant). After eight months of negotiations, Fiat signed a preliminary agreement with the $\mathrm{UOM}^{\top}$ (the metallurgical' union), which however decided to submit its ratification to a referendum amongst workers. The UOM wanted to start a new round of discussions to improve wages, but Fiat started separate negotiations with SMATA $^{8}$ (the machinists' union). In less than a week (a record!) a separate agreement was reached. Fiat's management refused to bargain with the strongly representative metalworkers' union, to sign a worse contract with SMATA at the expense of all the workers ${ }^{9}$.

The agreement between the company and SMATA included a salary adjustment for productivity - basically, a wage reduction - the figure of a polyvalent operator and hourly workers. Magically, the workers lost their seniority, their grades, their holiday entitlements and their production bonuses. Any worker who refused to be transferred from former Cormec to Smata was automatically dismissed.

Workers reacted to Fiat's offensive with two plant occupations and also by electing a new local Union leadership, but SMATA refused to let them organize their own local and to elect their representatives. Then Fiat workers voted overwhelmingly to establish an independent union, SITRAMF (Union of Machinists in Ferreyra), but the company and the government refused to recognize the independent union. So Fiat began to hit back at the workers: without delay, 42 workers were fired, including the elected representatives, while other union militants were eliminated through forced resignations (from January to October 1997 FIAT sacked 900 workers).

A statement by a Fiat-Cordoba worker illustrates the reasons for the union's loss of consent: "what happened was that the union left us many times alone, they abandoned us, did not do anything for the workers. When the factory was closed, we supported them, we gave support to the union to prevent, for example, people being fired. And there is, at the same time, a sort of diffidence. We have the union, but it's like we are ok with both Heaven and the devil. The union is a necessary evil".

This shows very clearly the difficulties unions have to deal with when facing a complete change in the rules, with consequences in terms of workers disaffiliation and disorientation.

\section{The New Organization Model and its Impact on Work Conditions}

In the new lean and mean (Harrison 1997) organizational model of Fiat Auto, and under pressure for a highly efficient and flexible work organization, work practices are only regulated to a

\footnotetext{
${ }^{6}$ The Unione Italiana del Lavoro, UIL, was born in 1950. It is of socialist and republican orientation and is the third most important Italian union.

${ }^{7}$ Unión Obrera Metalúrgica.

${ }^{8}$ Sindicato de Mecanicos y Afines del Transporte Automotor.

${ }^{9}$ This anomaly dates back to the 1970 s, when the Argentinean government, under pressure by Fiat, assigned by decree the union representation of Fiat plants to the UOM, removing it from SMATA, which at that time was a very militant union, while the UOM was mostly pro-government.
} 
limited extent by trade unions. The Italian case shows the extensive reduction of the 'job control style' experimented in the past (up to the end of the 1970s). Discussions on work conditions and work tasks do not include negotiations on specific changes in shop-floor organization, or on procedures to achieve agreement on these issues.

In the new production structure, besides their traditional manufacturing tasks, workers must formulate and apply micro-decisions in order to deal with 'micro-variations': that is, problems arising at the workstation level. Mobilization of all the competencies and resources available in the factory is a necessary condition for the new organizational system to operate successfully ${ }^{10}$. The new work organization is designed to respond in real time to difficult to predict - and therefore difficult to formalize - production events. At the same time, in response to workers' psychophysical stress and discontent, Fiat's management increased the level of panoptical control and, in some cases, the use of discipline and punishments in an unusually harsh version of Human Resource Management.

The World Class Manufacturing production system (WCM) is difficult to manage without the cooperation of the blue-collar workers and without participation by the unions, but despite management efforts to revise the Human Resource Management (HRM) approach, conditions are not satisfactory for the Fiat's workforce ${ }^{11}$.

A job in a car factory is accepted only in exchange for a wage, and it is difficult to create participation if the work conditions are laborious and stressful. At the same time, the work ethic has also changed over the past thirty years, and passive acceptance of a lifelong job of this kind has become increasingly problematic. Furthermore, as several studies have shown, the predominant feelings expressed by Fiat workers are disaffection, lack of involvement and a lack of commitment (Caputo 2004; Della Corte 2004; Caputo and Della Corte 2011).

Indicators like absenteeism, turnover, sickness, and dissatisfaction seem to confirm this trend (Bubbico 1999; Della Corte 2003). In particular, shifts, working hours, pay, discipline and control, harmful effects on health, are some of the critical issues highlighted by the workers. Although work is less heavy than before, work-related injuries like tendonitis and hernia still afflict many workers. As a Cordoba worker said: "The most common is tendinitis. Tendinitis due to the amount of repetitive work, your hand goes numb. Problems to the spine, lumbago, cervical pain, muscular. Sometimes my eyes close, as if I'm sleeping and the body keeps working"12.

At Melfi, for instance, something like 2,000-2,500 workers out of 5,000 complained of workrelated injuries and illnesses (Fiom-Cgil 2011). This also occurs at Mirafiori and in other plants. And the fatiguing and stressful work conditions are reflected in the high number of voluntary resignations (Della Corte 2004; Caputo 2004). The young workers interviewed often described their work as boring, stressful, and heavy. As a Fiat's Melfi worker said: "Many people left because they had accumulated excessive stress, because of both the heaviness of shifts and the atmosphere of the factory environment, the kind of life you live inside here".

In the Cordoba case, where working hours may well go beyond 10 hours a day, a worker stated: "I try to sleep more or less 4 or 5 hours [...] I get up at ten to five in the morning and leave home at five. I come back at a quarter to seven. We have a snack in the evening and then dinner, all in one go" ${ }^{\prime \prime}$.

Resentment and grievances can be linked to the perception of a low standard of work and unsatisfactory quality of life due to shifts and working hours, and the repetitiveness of tasks with no possibility of improvement or upgrading.

The consequent exacerbation of relations between the employees and the management has caused several forms of worker resistance, such as direct action within the factory (e.g. slowdowns, sabotage, etc.) and temporary or definitive defection from the company (in the form of absenteeism, sickness, retirement, and voluntary resignations). Some 600-700 workers left the Turin plants between 2000 and 2003 , whilst 1,800 out of about 5,000 workers left their jobs at Melfi between 1996 and 2001, a large number of which $(1,200)$ were resignations (Della Corte, 2004;

\footnotetext{
${ }^{10}$ Also because of this the new managerial models, as opposed to Taylorism, pretend ideologically to give the human being in its entirety back to the world of work (Boltanski and Chiapello 1999).

The World Class Manufacturing is the new Fiat's methodology to become an excellent company. The methodology is based on 20 pillars: 10 of managerial nature, which target the involvement of all employees, and 10 technical ones, which aim at the economic improvement of the company. The WCM can be considered a reinterpretation of the Japanese model of lean production, a model of organization, particularly widespread in big car companies, which relies primarily on two factors: the just-in-time system and the so called 'self-activation' (employee involvement). According to the Fiom-Cgil, the result of the implementation of the WCM was the reduction of breaks, with a consequent increase in the pace of work and effort.

${ }^{12}$ Interview with a Fiat worker in Cordoba, made by Lorena Capogrossi and Elisabetta Della Corte. Cordoba, 29 November 2010.

${ }^{13}$ Idem.
} 
Caputo and Della Corte 2009). This highlights a negative attitude among workers towards social relations at plant level: actual work conditions proved to be very different from those promised by the management when the Melfi factory opened. As was reported by an Italian worker: "At the beginning there was some enthusiasm amongst us. The change occurred two or three years later because nothing was new then, work is always the same and you're always doing the same things. At the beginning, the factory was born as an integrated factory [the Fiat version of the Japanese lean production] because each one of us was to be a protagonist, but you're not a protagonist, you're just a number inside there, first and foremost you have to carry out orders. We are not even allowed to speak, whilst there would be a lot of capable people here amongst us".

Moreover, some of the instruments used by the management to enhance internal flexibility, to reduce costs and to manage cyclical crises, have in some way encouraged the workers to leave.

The Fiat management has responded to this deteriorating situation by increasing control and hierarchical discipline. Strategies vary at management level, ranging from enforcing a strict regime of punishment for absenteeism to encouraging resignations. The managerial need to apply flexibility to the organization of work and to work hours is implemented by reducing redundant workers through the use of overtime, early retirements, Cassa Integrazione Guadagni $(\mathrm{CIG})^{14}$, mobility until retirement ${ }^{15}$, hiring temporary workers, exploiting high unemployment situations and the so-called 'atypical contracts' ${ }^{16}$ (to create a workforce sufficiently malleable to meet the stringent demands of lean production).

On the other hand, labour costs were reduced through de-verticalization/decentralization of production, trade-union collaboration, bargaining decentralization and public financial support.

Flexibility in the use of workforce, one of the fundamental prerequisites for the full operation of the new organizational principles of WCM, was pursued and ratified, both in Italy and in Argentina, by the implementation (or, rather, by the imposition) of new agreements with Unions, giving more power to the management: flexibility in the use of workers and new forms of industrial relations are closely related.

As far as industrial relations in general are concerned, research has shown how Trade Unions have serious difficulties in obtaining significant results. Despite recent attempts, the organization of work is still a management prerogative ${ }^{17}$. This finding is confirmed by weak and non-integrated forms of direct and indirect participation: direct participation is characterized by isolated and largely ineffective measures, or by limited impact in terms of decision-making decentralization. On the other hand, indirect participation is characterized by a limited ability to influence the organization of work and corporate strategies. In fact, the 'union participation' is managed by Fiat with the main purpose of guaranteeing a 'positive' social climate on the shop floor, which is essential for the lean workplace.

\section{New Companies and the Imposition of New Agreements - from Argentina to Italy}

When, in 1995, Fiat went back to Argentina, a new company was created: Fiat Auto Argentina (FAA), with the imposition of a new collective agreement. This agreement is aimed at increasing both production flexibility and managerial control, and also at reducing labour costs (by deleting all previous workers' rights and by cutting wages).

Such a strategy was adopted in 2010 in Italy. New agreements were first imposed in the Pomigliano d'Arco and Melfi plants, both in Southern Italy, under the threat of closing the sites to transfer production abroad, at that time at the historical Mirafiori plant in Turin.

At Pomigliano d'Arco and Turin a draft agreement was proposed to all unions and submitted to a referendum amongst the workers. This was a unilateral and populist decision rather than a democratic one: under the threat of dismissal, workers had to decide between working under the new conditions or being fired.

If we look more closely, on the one hand, the disciplinary model is inspired by the ideal of the 'democratic plant' model (Gaudemar 1982), although it still maintains some elements from the past

\footnotetext{
${ }^{14}$ The Cassa Integrazione Guadagni (C.I.G.) is a form of unemployment benefit authorized in case of ordinary, nonstructural market difficulties. It is allowed by the state and financed by both the employers and the workers. It has a temporary effect, where workers are not fired but simply suspended from work for a few months, receiving a benefit equalling $80 \%$ of the wage. Fiat has been using this instrument on a regular basis in recent years as part of a clear strategy for containing labour costs.

${ }^{15}$ Another form of unemployment benefit applied to workers with only a few years left before retirement.

${ }^{16}$ A series of non-conventional temporary work contracts instituted by the Law n. 30 of 2002.

${ }^{17}$ According to the Machine that Changed the World, for lean production to work, trade unions must be subordinated to the company's wider agenda of competitiveness and profitability.
} 
(panoptical technological surveillance, internal commission, etc.). The 'Democratic Plant' model, as Gaudemar said, is based, more than the previous one, on the on-force contract, presupposing that production effectiveness requires a certain democratic formalism. The referendum case at Pomigliano and Mirafiori is, in some way, the emblem of this festival of democracy, where the discursive power plays a great part in the construction of the 'new productive order'.

We can summarize Marchionne's discursive strategy in four main points:

Firstly, Fiat changed its image from that of a beneficiary of relevant public funds (Germano 2007 ) to that of a benefactor in times of crisis, promising lavish investments in order to save the Italian production and make new profits.

Secondly, a campaign against slackers was started through Marchionne's public statements: considering the amount of promised investments, the economic crisis and the ever-increasing competition, preventing sickness leave abuse becomes a vital issue. Marchionne was anticipated in 2008 by Minister Renato Brunetta's declarations against the abuse of sickness leave amongst public employees and by a media campaign against worker absenteeism at the Pomigliano plant, reinforcing an image of workers as "guaranteed" idle people, protected in particular by Fiom ${ }^{18}$. This was an attempt to divert public attention from the harsh reality of work conditions at Fiat, as was made clear by a sentence by judge Guariniello in Turin, where Fiat was responsible for hernias and carpal tunnel syndrome.

Thirdly, global competition between territories, production areas and markets are often mentioned as a threat to signal a possible abandonment of Italy. Marchionne has often compared the yields of the Italian sites with those of foreign neighbours (Poland and Serbia), threatening to transfer production abroad. Referring to the deal with Chrysler in Detroit, Marchionne always mentions the explicit gratitude of President Obama, exactly the opposite of what happens in Italy. The picture is complete with the complaints about the sales crisis in Europe as opposed to the expansion of the market in Latin American (Brazil and Argentina).

Finally, Fiat presented the referendum as an act of self-determination on the part of trade unions rather than what it was in reality: a unilateral expedient to overcome obstacles and objections, using the global crisis and competition as objective reasons to justify the worsening of work conditions.

In short, what emerges from the Marchionne model is an extremist version of Valletta's model of industrial relations, where the novelty is the attempt to hide the authoritarian aspects behind a curtain of communication (Perniola 2010), presenting unilateral decisions as objective and urgent choices. Fiat showed a vocation on building authoritarian and antagonistic industrial relations, that persists beyond the 'exogenous' (economic development and market position) and 'endogenous' terms (organizational model). "This has often led to contradictions between the model of industrial relations and the organizational model, with negative effects on the latter" (Rieser 2011b).

\section{The Agreement's Content}

The new Italian antagonistic industrial relations approach adopted by Marchionne recalls the latest Fiat strategy adopted in Argentina: it states a greater employee flexibility (more flexibility in work shifts through the introduction of 10-hour and night shifts), an intensification of work, controls on absenteeism, stricter rules for sickness leave, and the reduction of break time and, last but not least, the restriction of strike rights. On the other hand, Marchionne only 'promised' new investments (up to 1 billion Euros after 2012). The new labour contract was accepted by various trade unions but was refused by Fiom-Cgil, the most representative union in the Fiat plants.

As stressed by Rieser (2011), the core of the Mirafiori agreement is the substantial elimination of the national collective contract. In fact, all the clauses are non-modifiable and, according to the liability clause, the trade unions that signed the agreement cannot hold strikes aimed at changing any part of it. This jeopardises the basic function of a trade union, which is to achieve - even through conflict - an amelioration. Again, the agreement changes the traditional model of conflictnegotiation by creating a surrogate in place of negotiating joint committees. However, if an agreement in these various committees is not reached, the company unilaterally imposes its will (Rieser 2011).

The agreement also affects the rules of union representation, stating that the union representatives will be appointed only by the organizations that signed the agreement, thus excluding Fiom and its representatives.

\footnotetext{
${ }^{18}$ The Federazione Italiana Operai Metalmeccanici, FIOM, affiliated to Cgil, is the most representative mechanic Union both at national level and in the Fiat plants, at least before it was excluded due to the new agreements.
} 
As far as work conditions are concerned, the new agreement provides three variants of schedules and work shifts; 120 overtime hours per person, without prior consent of the Union, which may rise to 200 with the Union's consent; pauses are reduced from 40 to 30 minutes and, unlike at Mirafiori, Pomigliano has moved the 30-minute lunch break to the end of the shift on an experimental basis and discussed in the Joint Commission; to discourage absenteeism, the agreement states that the company can refuse to pay the first two days of sick leave for workers who fall ill close to vacations.

\section{The New Agreement and the Double Face of the Ergo-Uas Dispositive}

Work intensification is fundamental in the new agreement as a consequence of the enforcement of the new work metrics, Ergo-Uas ${ }^{19}$, introduced as a technical factor of the implementation of WCM at Fiat.

The Ergo-Uas system was introduced as an experiment at Mirafiori in $2008^{20}$, to re-define the time of implementation, taking into account factors of ergonomic risk (static and dynamic "biomechanic' charge, in particular) rather than technical-organisational factors (that also take into account factors such as relief, etc.).

Fiom contested such an experiment, claiming that the attention paid to the ergonomic aspects was only an excuse to intensify work well beyond any limit reached so far by Fiat ${ }^{21}$. Fiom (Tuccino 2010) states how the new metric, on the one hand, confirms more relief to a small number of heavy tasks, but on the other, cancels nearly all the 'relief factors' (i.e. recovery time, which sums up to execution times) of the bulk of operations not requiring particular physical stress, which now in many cases turn out to be saturated at $99 \%$ of the time, because a particular ergonomic 'difficulty' is not acknowledged, whilst before such 'saturation' for analogous positions varied from around 90$95 \%$, with a clear productive advantage for Fiat.

Furthermore, rest time will now be less than previously, when it used to be accumulated in a 20minute pause ${ }^{22}$. This is due to the new logic of Ergo Uas, justifying a further reduction of such a pause, i.e. an increase of productive time. As a matter of fact, this was already achieved with the elimination of the 10-minute pause in the agreements for Pomigliano and Mirafiori.

Fiom is therefore accusing Fiat of trying to intensify labour productivity by hiding behind the pretext of the scientific nature of a metric system which reduces rest time within the execution time, thus underestimating efforts and risks for health. For this reason, it contested the imposition of Ergo-Uas at Pomigliano and Mirafiori, refusing to sign for the experiment at Melfi, in April 2011.

At Melfi, also the less combative unions, such as $\mathrm{FIM}^{23}$, pointed out in the experiment phase the lack of effectiveness of the 'Commissione di Verifica' for Ergo-Uas (which is a joint commission), because the role of union representatives on the outcome of the experiment on new metrics is not acknowledged. In addition, delegates denounce a lack of clear information on how times are determined, due both to management being reluctant to reveal the measure of the higher work intensity, and also to an effective inability to produce precise data, because the new metric is often incoherent with a real re-definition of productive lines along more advanced ergonomic criteria ${ }^{24}$.

It is on this very ground that the real motivations of Fiat can be tested in introducing Ergo-Uas, which should include a new design of the whole productive layout according to ergonomics.

Interviews with workers during the experiment at Melfi make clear how, on the one hand, there was a high intensification of work and physical and mental stress on the job, and on the other not all the existing lines are characterised by ergonomicity; rather, they denounce an absence of significant innovation in this field, with some small insignificant solutions such as the fact that the components basket is now closer to the work position (to limit the time needed to walk there) and

19 UAS, Universal Analysis System, is a metric system, a method of working organization deriving from MTM (Methods Time Measurement), which was already applied in other car factories in the world, to which a check-list is associated for the analysis of ergonomic risk factors, called Ergo (European Assembly Work-Sheet)

20 This happens in spite of what was established by previous agreements in the field of organizational experiments, in particular the agreement of 5 August 1971.

21 The alleged scientific nature of Eaws check-list Eaws was also criticised by independent technical bodies, such as Società Nazionale Operatori della Prevenzione (Snop) which, in comparison with the Associazione MTM Italia (www.snop.it), stressed how the working of this system is not fully known and it is less effective as opposed to more wellknown and widespread systems, such as OCRA INDEX

22 To this pause a further 20-minute pause is added, corresponding to the accumulation of the so-called 'physiologic factor', calculated as $4 \%$ of the total shift time.

${ }^{23}$ The Federazione Italiana Metalmeccanici, Fim, affiliated to Cisl, of Catholic inspiration.

24 Unions believe that minor problems generated by the new metric experiment in other plants, such as Mirafiori, are due to a higher precision in its implementation compared to Melfi. 
some other expedients which had clearly been invented on the spot resulting in the workers refusing them immediately, with no reaction from Fiat.

According to the agreement, the new WCM and Ergo/Uas systems should solve the physical problems and the stress caused by the previous model. However, so far, there is no evidence of this. In fact, our research in Cordoba indicates that work conditions have deteriorated. In Fiat-Melfi, some workers with physical limitations were made redundant ("now they're starting to fire 'the limited'", as a worker of Melfi put it) and confined in isolated departments.

\section{Conclusion}

The world car industry has long been afflicted by an impressive excess of productive capacity, estimated at around $40 \%$. As a consequence, car corporations are fighting each other on the grounds of car prices. The new imperatives are streamlining, modularization, outsourcing. The tendency of the new productive paradigm can be summed up as a new use of territories ${ }^{25}$ in order to conquer wider scale and scope economics (with significant repercussions on industrial relations and work conditions); in greater competition between the different productive sites of the same corporation ${ }^{26}$, thanks to systems of parallel production, also taking into account public incentive, tax relief, services, the reduction of labour costs and the increase in working time flexibilization (which generally imply reductions in labour standards and work conditions).

As Luciano Gallino noted: ${ }^{27}$ "at the expense of suppliers (responsible for two thirds of the added value of the car), local communities who all of a sudden see a factory disappearing, and the workers of the final assembly. Car makers unable to extirpate even the last Euro from all these subjects are out of the market".

The Argentinean and Italian cases highlight how the parallel processes of introducing flexibility, fragmentation, work precarization and contractual deregulation involves all countries at different levels and with a different timing, and it is aimed, in the last instance, at transforming labour into a variable which is totally dependent on the values and budgets of corporations. The experience of the last 10-15 years of Fiat in the Argentine has somehow anticipated what is happening in Italy today in terms of work conditions, discipline of the workforce and in the field of industrial relations. ${ }^{28}$

In this sense, in Italy worker rights have undergone an accelerated process of erosion as well. For example, since 2010 FIAT plants at Pomigliano d'Arco and Turin are no longer covered by the national collective work agreement. This strategy adopted by Marchionne has been justified as a consequence of globalization. It should not be confused as a necessity, but as a managerial choice: "There are clear indications that the concessions demanded by Fiat will have very little impact on its global competitiveness [...]. The crucial question is whether greater internal flexibility of labour deployment, and prolongation and intensification of work, can solve all of Fiat's problems and miraculously restore competitiveness in a sector affected by worldwide overcapacity of supply and reduction of demand" (Nuti 2011, 252-253).

It is clear how the actual negotiation and decision-making process exhibits structural asymmetries between Fiat management and the representatives' power, where the latter is subordinate to the former. On the other hand, the current socio-economic situation, closest to the depression crisis, is far from the economic boom euphoria. To bend this adversity to one's advantage, ambitious but achievable plans for the automotive sector where implemented, based on the weapons of relocation, plant closure and worker dismissal in order to produce consensus, participation, self-discipline and to win the referendum and impose a new agreement, no matter whether it be for the worse.

In conclusion, we can say that industrial relations at Fiat are still instrumental to managerial needs alone. In any case, Fiat has always wanted the unions to be subordinate (which means that they should not enter company management). This patriarchal attitude, embedded in the Group's heritage and history, hampers the company's ability to implement its new model and reinforces workforce hostility towards the management. How can this new management be 'productive' by 'democracy' and fear?

\footnotetext{
${ }^{25}$ States, regions, local contexts.

${ }^{26}$ Which contributes to make employment insecure and Union shop stewards vulnerable with regard to the requests of the management.

27 "La Repubblica", June 14, 2010.

${ }^{28}$ As Luciano Gallino noted (see n. 28) "The economic crisis exploded in 2007 has dropped the veils of globalisation. Politicians, managers, analysts are no longer scared of saying that the problem is not that of raising wages and work conditions in the emerging countries: it is our countries that should, for a sense of responsibility, go down to their level".
} 


\section{References}

Accornero, Aris, Alessandro Pizzorno, and Mario Tronti. 1977. Movimento sindacale e società italiana. Milano: Feltrinelli. Bélis-Bergouignan, Marie C., Gerard Bordenave, and Yannick Lung. 2000. Global Strategies in the Automotive Industry. Regional Studies 34 (1): 41-53.

Bellman, Steven et al. 2004. International Differences in Information Privacy Concerns: A Global Survey of Consumers. The Information Society 20 (5): 313-324.

Berta, Giuseppe. 2011. Fiat Chrysler e la deriva dell'talia industriale. Bologna: II Mulino.

Boltanski, Luc, and Ėve Chiapello. 1999. Le nouvel esprit du capitalism. Paris: Gallimard.

Borrus, Michael, and John Zysman. 1997. Globalization with Borders: The Rise of Wintelism as the Future of Global Competition. Industry and Innovation 4: 144-166.

Boyer, Robert, and Michel Freyssenet. 2003. Produktionsmodelle. Eine Typologie am Beispiel der Automobilindustrie. Berlin: Edition Sigma.

Bubbico, Davide.1998. La fabbrica al lavoro, ovvero l'assenteismo del lavoratore. Finesecolo 4/5 (1): 81-91.

Caputo, Paolo. 2004. Il tallone di Achille. Melfi: la vulnerabilità della produzione snella. Pozzuoli: Immaginapoli.

Della Corte, Elisabetta. 2003. Quando la fabbrica delude. Pubblicazioni della Regione Basilicata vol. 2. Potenza: Regione Basilicata.

Della Corte, Elisabetta. 2004. Evasioni. Melfi: fuga dalla fabbrica penitenziario e altre storie. Pozzuoli: Immaginapoli.

Caputo, Paolo, and Elisabetta Della Corte. 2009. La lotteria dell'auto. L'industria automobilistica dall'egemonia al crollo. Roma: Carocci.

Caputo, Paolo, and Elisabetta Della Corte. 2010. "Mutaciòn de la fábrica y del trabajo en la era de la globalización: el caso Fiat (Argentina y Italia)." Paper presented at the II Jornadas Internacionales de Problemas Latinoamericanos. Universidad Nacional de Córdoba, Argentina, November 18-20.

Gallino, Luciano. 2000. Globalizzazione e disuguaglianze. Roma-Bari: Laterza.

Gallino, Luciano. 2007. II lavoro non è una merce. Contro la flessibilità. Roma-Bari: Laterza.

Gaudemar, Jean P. 1982. L'ordre de la production: Naissance et formes de la discipline d'usine. Paris: Bordas.

Giacchetti, Diego, and Marco Scavino. 1999. La Fiat in mano agli operai: L'autunno caldo del 1969. Pisa: BFS Edizioni.

Harrison, Bennett. 1997. Lean and Mean: Why Large Corporations Will Continue to Dominate the Global Economy. New York: Guilford Press.

Harvey, David. 2010. The Enigma of Capital and the Crises of Capitalism. New York: Oxford University Press.

Jürgens, Ulrich et.al. 2003. Paradigmenkonkurrenz der Industriegovernance zwischen Alter und Neuer Ökonomie. Industrielle Beziehungen 10 (3): 393-417.

Motta, Jorge. and Maria I. Barbero. 2007. Trayectoria de la industria automotriz en la Argentina desde sus inicios hasta fines de la década de 1990. In Innovación y empleo en tramas productivas de Argentina, edited by.Marcelo Delfini et al. Argentina: UNGS. Prometeo Libros..

Nuti, Domenico M. 2011. Industrial Relations at FIAT: Dr Marchionne's Class War. Review of Labour and Research. 2011. 17 (2): 251-254.

Perniola, Mario. 2009. Miracoli e traumi della comunicazione. Torino: Einaudi.

Rieser, Vittorio. 2011a. Verso una marchionnizzazione delle relazioni industriali?. Accessed January 31, 2011. http://www.sindacalmente.org/content/marchionnizzazione-delle-relazioni-industriali-vrieser-sindacato-31111.

Rieser, Vittorio. 2011b. Appunti schematici su modello organizzativo e relazioni industriali alla Fiat. Accessed April 5, 2011. http://www.sindacalmente.org/content/le-relazioni-sindacali-alla-fiat-vrieser-e-fciafaloni-seminario-5411.

Rinehart James, Christopher Huxley, and David Robertson. 1997. Just Another Car Factory? Lean Production and its Discontents. New York: Cornell University Press.

Sewell, Graham, and Barry Wilkinson. 1992. Someone to Watch Over Me: Surveillance, Discipline and the Just In Time Labour Process. Sociology 26 (2): 271-289.

Tomadoni, Claudia. 2009. Los autos nunca compran autos: territorio, restructuraciòn y crisis en la industria automotriz. Cordoba AR: Encentro.

Tuccino, Francesco. 2010. World Class Manufacturing e sistema ErgoUas, Accessed September 10, 2010. http://www.fiom.cgil.it/auto/fiat/.../10 09 10-saggioWCM Ergouas.pdf

Womack, James P., Daniel T. Jones, and Daniel Roos. 1990. The Machine that Changed the World: The Triumph of Lean Production. New York: Macmillan.

\section{About the Authors}

Paolo Caputo

is Researcher in Sociology of Economics and Work at the Faculty of Economics (University of Calabria).

Research interests: Changes in production process; Post-Fordist production; work organisation; human resources management; trade union organisation; globalisation and labour relations; labour flexibility; social and economic change.

Teaching duties: Professorship in Sociology of Economic Process and Labour at the University of Calabria.

His books include: The Labour Impact of Globalization in the Automotive Industry. A Comparison of the Italian, German, Spanish and Hungarian Motor Industries (2008); La lotteria dell'auto. L'industria automobilistica dall'egemonia al crollo (2009); Trabajar en team en la Fiat: de Melfi a Cordoba (2004).

Antonino Campenni

is Researcher in Sociology of Environment and Territory at the Dipartimento di Sociologia e di Scienza Politica, Università della Calabria, Rende, Italy.

Research Interests: urban sociology, labour market, unemployment, trade unions, social exclusion

Teaching: Sociology of Territory.

Publications: L'egemonia breve. La parabola del salariato di fabbrica a Crotone (2002); In morte di una fabbrica (2005); Lavoro e stratificazione sociale (2010) 
Elisabetta Della Corte

works as researcher in Sociology of Economics and Work at the Department of Sociology and Political Science, University of Calabria. Over the years she has taught Sociology of Economic Process and Labour, Sociology of Consumption, Analysis of Complex Societies, Local development. Her main research fields are: capitalism and crisis; innovation technology; working organization; surveillance; alienation and resistance; globalization and labour relation; immigration studies; common goods and movements in South Italy. Her qualitative research on automotive industry and container ports has been conducted in South Italy, in England and Argentina. Her publications include: II lavoro sul fronte dei porti a Gioia Tauro, Southampton, Felixtowe (2002); Quando la fabbrica delude, esodo e licenziamenti in Fiat-Sata (2003); The Labour Impact of Globalization in the Automotive Industry. A Comparison of the Italian, German, Spanish and Hungarian Motor Industries (2008); La lotteria dell'auto. L'industria automobilistica dall'egemonia al crollo (2009). She writes for magazines and newspapers, and she animate independent news sites such as Esodoweb.net, Terrecomuni.blogspot.com and Ciroma.info. 